\title{
ТЕОРЕТИКО-МЕТОДОЛОГІЧНИЙ БАЗИС РОЗВИТКУ ОРГАНІЗАЦЙНОЇ КУЛЬТУРИ В ТЕОРІЇ ТА ПРАКТИЦІ УПРАВЛІННЯ ЗАГАЛЬНООСВІТНІМ НАВЧАЛЬНИМ ЗАКЛАДОМ
}

У пропонованій статті висвітленні тенденції становлення та розвитку організаційної культури керівних кадрів системи освіти. Розкриті концептуальні погляди на зміст організаційної культури керівників загальноосвітніх навчальних закладів. Обгрунтована потреба використання керівниками в практиці управління навчальним закладом елементів організаційної культури та відсутністю розроблених алгоритмів іiі розвитку як складової управління розвитком професійної компетентності педагогів. Позиціонується прагнення до адекватного розв'язання актуальних управлінських проблем та пошуку нових шляхів їх вирішення, дотримання норм соціально відповідальної поведінки керівників навчальних закладів, розвитку організаційної культури як детермінуючого фактора іï ефективності, - усе це забезпечує сутність теоретико-методологічних засад результативного виконання професійно-управлінської діяльності, формування позитивного образу управлінця нового типу.

Ключові слова: організаційна культура, організаційна культура ЗН3, організаційна культура керівника ЗНЗ, управлінська діяльність. 
2016 - № 3 (49)

В данной статье освещены тенденции становления и развития организационной культуры руководящих кадров системы образования. Раскрыты концептуальные взгляды на содержание организационной культуры руководителей общеобразовательных учебных заведений. Обусловлена необходимость использования руководителями элементов организационной культуры в практике управления учебным заведением и отсутствием разработанных алгоритмов ее развития как составляющей управления развитием профессиональной компетентности педагогов. Позиционируется стремление к адекватному решению актуальных управленческих проблем и пути их решения, соблюдение норм социально ответственного поведения руководителей учебных заведений, развития организационной культуры как детерминирующего фактора еe эффективности - все это обеспечивает сущность теоретикометодологических основ результативного исполнения профессиональноуправленческой деятельности, формирование позитивного образа управленца нового типа.

Ключевые слова: организационная культура, организационная культура школы, организационная культура руководителя школы, руководитель школы, управленческая деятельность.

Актуальність дослідження обумовлена потребою використання керівниками в практиці управління навчальним закладом елементів організаційної культури та недостатністю розроблених алгоритмів розвитку організаційної культури як основної складової успішного розвитку навчального закладу.

Дослідження організаційної культури (як явище) у світовій теорії і практиці управління почали розвиватися в рамках гуманістичного підходу до організації та управління людьми в ній, де основним завданням управління вважається адаптація організації до зовнішнього середовища і його подальша зміна на засадах розвитку організаційної культури, яка допомагає впливати на діяльність організації через встановлені цінності, норми, традиції, мову тощо; що озброює керівників системою понять, цінностей, умінь, навичок та компетентностей та перетворює стереотипне керівництво людьми на осмислене і зрозуміле.

До наукових здобутків у цій галузі необхідно віднести розробки із загальних філософських питань культури - зокрема, таких авторів, як В. Андрущенко, Є. Бистрицький, А. Бистрова, В. Бодак, Д. Гудков, П. Гуревич, I. Дзюба, В. Заблоцький, С. Іконнікова, М. Каган, 
2016 - № 3 (49)

В. Каганський, Л. Коган, С. Кримський, . Парахонський, I. Предборська, Н. Скотна, В. Табачковський, В. Шинкарук. Проблематика організаційної культури більшою мірою розроблена в працях західних дослідників - таких, як П. Вейл, С. Девіс, М. Елвессон, П. Ентоні, Дж. Мартін, Д. Мейерсон, Р. Моран, Д. Ньюстром, А. Петтігрю, Т. Пітерс, К. Рей, Р. Розенфельд, В. Сате, Л. Смірцих, Г. Сміт, В. Співак, Е. Уілкінз, Р. Уотерман, П. Харріс, Ч. Хенді, Е. Шейн. До психологічних чинників формування організаційної культури зверталися Д. Боллінже, Дж. Дістефано, Г. Лейн, В. Оучі, Г. Хофстеде. Окремі аспекти організаційної культури, зокрема в бізнесових та освітніх організаціях, вивчалися зарубіжними (В. Томілов, С. Рощин, В. Снєтков та ін.) та українськими (Л. Карамушка, В. Лозниця, Л. Орбан-Лембрик, Ю. Палеха, І. Савка, Г. Тимошко, О. Францев та ін.) вченими. Ця проблема знайшла своє відображення в дисертаційних роботах 3 питань дослідження організаційної культури в галузі: педагогіки (В. Виноградова, М. Гедієва, Н. Іорданова, Г. Літовченко. Н. Стрижак та ін.); психології (В. Воронін, С. Липатов, Ж. Серкіс); соціології (Н. Зубрева, А. Капітонов, С. Юр'єва та ін.). Аналіз останніх досліджень і публікацій свідчить про те, що в педагогічній теорії і практиці зростає кількість наукових розвідок із порушеної проблеми, що свідчить про пильну увагу вчених до цього питання. Натомість, разом із наявними успіхами у вивченні проблеми, ми виокремлюємо як недостатньо вивчене питання - теоретикометодологічні засади розвитку організаційної культури в теорії і практиці управління навчальними закладами.

Метою статmі $\epsilon$ розкриття теоретико-методологічних засад розвитку організаційної культури в педагогічній теорії і практиці управління загальноосвітніми навчальними закладами.

Демократичне управління характеризується поділом влади i участі працівників в управлінні, при цьому відповідальність не концентрується, а розподіляється згідно 3 переданими повноваженнями. Залежно від характеристик виконуваної задачі окремі працівники і групи виявляють різний рівень «зрілості». Керівник повинен оцінити цей ступінь зрілості й відповідний стиль управління. 
2016 - № 3 (49)

Сучасні загальноосвітні навчальні заклади (ЗН3) були й залишаються демократичними закладами: вони надають освітні послуги всім дітям, які бажають у них навчатися. Проте ЗНЗ стають більш самостійними, а це означає, що вони стають більш соціально відповідальними. Виконуючи освітні послуги, школи існують перш за все для учнів, мають своє обличчя, свою поведінку, свою манеру реагування на зовнішнє середовище, неповторну індивідуальність, можливості, здібності, уміння, компетентність, утверджують у суспільстві свою організаційну культуру.

Організаційна культура - це притаманна організації система традицій, вірувань, цінностей, символів, ритуалів, міфів, норм спілкування між людьми. Організаційна культура надає організації індивідуальність, формує власний позитивний імідж. Загалом організаційна культура будь-якого типу дозволяє здійснювати вирішення різних управлінських проблем, серед яких можна виділити наступні: комунікаційні бар'єри у співпраці; розходження в стилях управління; відмінності в мотивації праці; відмінності в постановці проблем і прийнятті рішень; різноманітність у соціальнокультурної компетенції і розвитку персоналу [10].

Навчальні заклади розвиваються за своїми особливими, притаманними тільки їм внутрішніми закономірностями, за своєю організаційною культурою, яку обов'язково треба враховувати в процесі ефективного управління навчальним закладом. Організаційна культура - це нова сфера знань, яка входить до серії управлінських наук. Вона виділилася з порівняно нової сфери знань організаційної поведінки, що вивчає загальні підходи, принципи, закони та закономірності в певній організації і $є$ складовою поняття і явища - культура управління. У сучасній літературі існує досить багато визначень поняття «організаційна культура», яке розглядається в контексті поняття «культура». Розглянемо найбільш поширені:

«Культура являє собою набір важливих установок (часто таких, що їх неможливо усвідомити і сформулювати), які поділяють члени того чи іншого суспільства» (В. Сате, 1982 р.).

«Культура в метафоричному розумінні - це один із способів здійснення організаційної діяльності за допомогою мови, фольклору, традицій та інших засобів передачі основних цінностей, переконань, 


\section{6 - № 3 (49)}

ідеології, що спрямовують діяльність підприємства в потрібне русло» (М. Морган, 1986 р.).

«Корпоративна культура являє собою неявну, невидиму й неформальну свідомість організації, що керує поведінкою людей i, y свою чергу, сама формується під впливом їхньої поведінки» (К. Шольц, 1987 р.).

«Культура - це система відносин, дій і артефактів, що витримує іспит часом і формує в членів певного культурного суспільства досить унікальну загальну для них психологію» (П. Вейлл, 2001 р.).

«Організаційна культура - це набір прийомів і правил вирішення проблем зовнішньої адаптації і внутрішньої інтеграції працівників, правил, що виправдали себе в минулому й підтвердили свою актуальність» (Е. Шейн, 1996 р.).

На думку Е. Брауна, організаційна культура - це набір переконань, цінностей i засвоєних способів вирішення реальних проблем, що сформувався за час життя організації і має тенденцію прояву в різних матеріальних формах і в управлінні організацією.

Наявність організаційної культури визнає як академічна наука, так і сфера адміністративно-ділових кіл, однак щодо змістовного трактування іiі визначень такої єдиної загальноприйнятої думки немає.

На нашу думку, наявні визначення далекі від універсальності й відбивають лише різноманітні функціональні прояви культурної царини, що формулюються по-різному залежно від конкретних цілей дослідження. Так, сучасна суспільствознавча думка в межах поняття «організаційна культура» розглядає визнані цінності, переконання, норми і форми поведінки в організації; усе, що визначає унікальність характеру організації; набір найбільш важливих припущень, що приймаються членами організації i втілюються у вигляді організаційних цінностей, задають людям оріснтири їхньої поведінки й дій і передаються індивідам через «символічні» засоби духовного і матеріального внутрішньо-організаційного середовища.

3 опорою на організаційно-діяльнісний підхід в управлінні організацією виокремлюється явище i поняття «організаційна культура управління», яку здійснює керівник організації [5; 7].

Управління як сфера людської діяльності виникло разом із формуванням соціуму - сукупності людей, що існують, певним 
чином взаємодіючи між собою в процесі спільного виконання тих чи інших робіт. Визначальним етапом у розвитку управління стало зародження і становлення державності. Перші приклади свідомого управління відносяться ще до V-III тисячоліть до н. е., що було зафіксовано на глиняних табличках, які дійшли до наших днів i засвідчили існування певного регламенту управлінської діяльності в Двньому Сгипті та Шумерії, пов'язаного з комерційними операціями й управлінням державою.

У давньоєгипетській пам'ятці писемності «Повчання Птаххотепа», датованій 2000-1500 pр. до н. е., також розглядаються найважливіші питання управління державою: сутність влади, значення стилю і методів керівництва.

Мислителі Давньої Греції також зробили свій внесок у розвиток науки управління. Зокрема, Сократ, підкреслюючи важливість поділу праці і спеціалізації, бачив завдання управління у тому, щоб поставити кожну людину на належне їй місце. Він та інші давньогрецькі філософи стверджували, що причиною бідності суспільства, як правило, є відсутність кваліфікованого керівництва. Платон у своїх «Політичних діалогах», «Республіці» і «Законах» виклав теорію «ідеальної держави». Вищесказане свідчить, що людство вже давно усвідомило важливість управління як особливого виду діяльності. Але як галузь управлінських знань менеджмент почав формуватися в другій половині XVIII ст., а його становлення відбувалось на початку XX ст., в епоху індустріалізації і народження величезних за масштабами діяльності організацій. Ціла плеяда наукових шкіл розвитку процесу управління в кінці XVIII ст. - на початку XIX ст. створила нову парадигму наукових поглядів на процес управління.

Зазначимо, що в сучасних умовах поширена думка про те, що процес управління $\epsilon$ мистецтвом, сутність якого полягає в застосуванні науки до реальної ситуації на практиці. Без знання технології управління в сучасних умовах неможливо ефективно керувати організацією.

3 наукового погляду управління - це спрямована координація й організація об'єкта управлінського впливу, з допомогою яких людина впливає на технологічні, економічні i соціальні процеси для досягнення визначених цілей [4]. 
2016 - № 3 (49)

Упровадження ринкових відносин у практику господарювання вимагає принципової зміни методів управління на всіх рівнях управлінської ієрархії. Цим обумовлюється вивчення нових підходів i форм управління, зокрема, менеджменту як особливого виду управління. Менеджмент як наукова дисципліна пройшов довгий $\mathrm{i}$ суперечливий шлях становлення, i розглядати його потрібно 3 урахуванням історичного досвіду та цілей i задач, які були характерними для різних етапів розвитку суспільства.

Термін «менеджмент» походить від англ. «to manage» і означає «керувати», «очолювати», «завідувати», «бути здатним впоратися 3 чимось, якоюсь проблемою». Менеджмент слід представляти як науку і мистецтво перемагати, вміння досягати поставлених цілей, використовуючи працю, мотиви поведінки та інтелект людей. У процесі менеджменту здійснюється цілеспрямований вплив на людей 3 метою перетворення неорганізованих елементів на ефективну i продуктивну силу [6].

Демократизація суспільного життя країни дозволила широким верствам населення ознайомитися 3 накопиченим багатим світовим досвідом теорії і практики менеджменту, а орієнтація української економіки на ринкові відносини зробила просто необхідними вивчення й використання досвіду передових держав, із яким ми детально ознайомились у процесі педагогічного дослідження i переконалися, що запровадження ринкових відносин у практику господарювання вимагає принципової зміни методів менеджменту на всіх рівнях управлінської ієрархії. Це висуває необхідність вивчення нових підходів і форм управління, зокрема менеджменту як особливого типу управління [3;8].

Основна мета менеджменту - досягнення високої ефективності виробництва, кращого використання ресурсного потенціалу підприємства, фірми, компанії; досконале керівництво організацією. Таке трактування менеджменту $\epsilon$ дещо ближчим до поняття управління організацією, хоча й зберігає істотні відмінності.

Управлінська практика свідчить про наявність серйозного стратегічного повороту управлінських підходів у напрямі посилення уваги до людської, насамперед професійно-культурної складової діяльності сучасних організацій. При цьому найбільш важливим 
2016 - № 3 (49)

аспектом аналізу стає представлення про цілісність організаційноуправлінського контексту функціонування й розвитку організації.

Ми розділясмо думку багатьох вітчизняних i зарубіжних дослідників, що в класичному менеджменті організащія- це систематизоване, свідоме об'єднання дії людей для досягнення певних цілей. В іншому аспекті організація- це і функція педагогічного менеджменту, i процес об'єднання членів педагогічного колективу для досягнення цілей, які визначені суспільством.

Управління освітніми організаціями є різновидом соціального управління. Це сучасний напрямок управлінської діяльності, яка спрямована на досягнення установами освіти, що діють у ринкових умовах, визначених цілей шляхом раціонального використання матеріальних, людських та інших ресурсів із застосуванням науково обгрунтованих форм, принципів, функцій i методів. Отже, управління - це цілеспрямований вплив на певний об'єкт із метою зміни його стану або поведінки.

Глибокі соціальні й економічні зрушення, що відбулися на межі третього тисячоліття в Україні, спонукали до перегляду досліджень у галузі управління, звернення до світового досвіду країн, що існують в умовах ринку та накопичили колосальні управлінські знання. Результати педагогічних досліджень (В. Бегей, В. Бондар, Л. Даниленко, Г. Сльникова, Н. Островерхова, В. Олійник, Л. Калініна, В. Маслов, В. Пікельна, Т. Сорочан, С. Хриков та ін.) засвідчують, що в сучасних умовах управління школою стає професійною діяльністю, зміст якої виходить за межі педагогічних знань, він вимагає оволодіння педагогічним менеджментом.

Основою будь-якої концепції є методологія, де аксіологічна система визначає принципи, методи і зміст діяльності, у даному випадку управлінської. Людиноцентричний погляд у менеджменті сьогодні - його методологічна основа, базисна установка, яка пронизує управлінські підходи і програми практично всіх успішних фірм, корпорацій, об'єднань у різних країнах і сферах. Педагогічний менеджмент повинен відображати, на нашу думку, не стільки професійну сферу його вживання, скільки людиноцентичний зміст діяльності педагога-управлінця. 
2016 - № 3 (49)

Успіхи щодо розвитку та основних показників діяльності підприємств, установ та організацій в умовах трансформації економіки і соціальної сфери України визначають для держави можливість поступового іiі входження у світове співтовариство, інтеграцію в європейські структури, за умови розв'язання проблем стратегічного менеджменту і як наслідок - формування належного рівня організаційної культури на всіх рівнях управління.

Значення і роль організаційної культури були усвідомлені практиками i теоретиками менеджменту не відразу. Інтерес до культурних особливостей організації з'явився приблизно в кінці 70-х років XX століття і був викликаний переоцінкою ролі персоналу в діяльності організації, а також служби персоналу в системі управління організацією. Тема організаційної культури почала активно обговорюватися з 60-70-х років XX століття. Проте істотний крок зроблений у 80-х роках XX століття Едгаром Шейном.

На наше глибоке переконання, у ході трансформації організаційної культури керівник зіштовхується 3 чотирма проблемами:

- опір домінуючої організаційної культури, що являє собою накопичений i часто неусвідомлений позитивний досвід, який приносив бажані результати в минулому;

- складність зміни культури як такої: неофіційно прийняті й діючі процеси, ритуали, структура влади i типи поведінки реалізуються в складних мережах взаємопов'язаних факторів і не можуть бути змінені відразу, ізольовано один від одного;

- суперечності в образі бажаної культури: у більшості випадків зміна культури заперечує вічний пошук вищого керівництва збільшення їх підконтрольності при декларуванні автономності, творчості та інновації.

Проблематика організаційної культури багатогранна, відносно нова для суспільства й недостатньо досліджена наукою. У зв'язку 3 тим, що організаційна культура перебуває на перетині таких наук, як менеджмент, психологія, культурологія, педагогіка, соціологія, філософія та ін., вона потребує комплексних наукових досліджень на засадах системного підходу за участю фахівців різного профілю [9].

Багато із дослідників сходяться на думці, що більшість проблем, пов'язаних 3 неможливістю добитися яких-небудь змін, навіть за 
наявності бажання зробити це, виникають під впливом організаційної культури керівника [2].

Життєва аксіома стверджує: культуру створюють люди, i сповідують іiі теж люди. Організаційна культура $\epsilon$ основою життєвого потенціалу такого складного організму, як організація: це те, заради чого люди стали членами організації; те, як будуються відносини між ними; які стійкі норми та принципи життя та діяльності організації вони поділяють; що, на їхню думку, добре, а що погано, і багато іншого 3 того, що відноситься до цінностей і норм. Усе це не тільки відрізняє одну організацію від іншої, але й істотно зумовлює успіх функціонування організації в довгостроковій перспективі.

Носіями ж культури в організації є люди. Однак в організаціях 3 усталеною культурою вона стає атрибутом організації, ії частиною, що надає активний вплив на членів організації, що модифікує їх поведінку у відповідності з тими нормами i цінностями, які становлять їі основу.

Зростаючий останнім часом науковий і практичний інтерес до феномена організаційної культури свідчить про прагнення сучасного менеджменту при впровадженні нових форм управління використовувати цей потенціал 3 метою гармонізації соціальнотрудових відносин, створення унікального фірмового стилю, що зрештою сприяє зростанню нематеріальних активів певної спільноти і посиленню її конкурентоздатності [1].

Базується організаційна культура на життєвих цінностях членів організації, спільноти, пї не можна сформувати за короткий час шляхом написання відповідних документів, положень і інструкцій. Через свій міждисциплінарний характер проблеми культури членів організації знаходяться у сфері інтересів різних галузей знання (економічної теорії, культурології, соціальної філософії, соціології, організаційної психології, етики, організаційної поведінки тощо) [11].

Одним із актуальних напрямків реформування системи управління закладами освіти є формування організаційної культури педагогічних кадрів, на які відтепер покладено провідну роль у здійсненні інноваційних перетворень у галузі навчання і виховання учнів загальноосвітніх навчальних закладів. У зв’язку 3 цим 
2016 - № 3 (49)

особливої значущості набуває проблема творчої самореалізації особистості сучасного керівника загальноосвітнього навчального закладу як менеджера навчально-пізнавального і освітньо-виховного процесу. Такий підхід набуває практичної значущості в безпосередньому здійсненні та усвідомленні процесу формування організаційної культури керівника загальноосвітнього навчального закладу.

Педагогічна практика підтверджує, що важливим інститутом творення культури від керівника до вчителя або до учня $є$ сучасний загальноосвітній навчальний заклад, а принципи гуманізації та гуманітаризації освіти спонукають керівників підносити статус їх культурологічного підходу в управлінні загальноосвітнім навчальним закладом.

Аналіз літературних джерел та багаторічна управлінська практика дозволяє зробити висновок, що організаційна культура розглядалася 3 позицій різних наукових дисциплін i $\epsilon$ міждисциплінарним поняттям. В умовах ціннісних змін і соціокультурної динаміки сучасної України формування організаційної культури набуває особливої актуальності.

Сучасна педагогіка має визнати, що метою освіти є входження вихованця в простір культури, активне іiі засвоєння, творення нових культурних цінностей. Цей процес відбувається в культурноосвітньому соціальному середовищі, у якому можлива співпраця суб'єктів соціально-освітнього середовища, без якої середовище не можна вважати культурним. Ресурси справді культурного соціального середовища, на думку багатьох дослідників, $\epsilon$ невичерпними. Отже, проектуючи розвиток освітнього закладу, керівникам необхідно забезпечити його культуровідповідність у сучасному соціумі.

Справді культурним має бути і сам процес управління ЗНЗ - від його філософської, моральної платформи до організаційної i технологічної. Світовий досвід показав, що організаційна культура в управлінні сприяє успіху в досягненні цілей, а значить - високій якості освітніх послуг, які продукує сучасний загальноосвітній навчальний заклад. 
2016 - № 3 (49)

\section{Література}

1. Акімова О. Організаційна культура державного службовця в умовах розбудови українського суспільства / О. Акімова // Вісник НАДУ. - 2005. №1. - С. 147-152. 2. Болгаріна В. С. Культурологічний підхід як імператив управління сучасною школою / В. С. Болгаріна // Культурологічний підхід до управління школою. - Х. : Основа, 2006. - 112 с. - (Б-ка журн. «Управління школою» ; Вип. 5(41)) - С. 40-50. 3. Даниленко Л. Основні напрями розвитку менеджменту освітніх інновацій / Л. Даниленко // Менеджмент інновацій в освіті. - К. : Шк. світ, 2007. - (Б-ка «Шк. світу»). С. 82-95. 4. Зиновьев Ф. Управленческое консультирование : [монография]/ Ф. Зиновьев, Н. Лобанов, В. Тебенко. - Симферополь : Таврия, 2000. - 154 с. 5. Мармаза О. І. Організаційна культура управління / О. І. Мармаза // Управління школою. - 2003. - № 7. - С. 19-23. 6. Международный менеджмент / [под ред. С. Э. Пивоварова, Л. С. Тарасевича, А. И. Майзеля]. - СПб. : Питер, 2002. - 576 c. 7. Серкіс Ж. В. Проблеми управління організаційною культурою Ж. В. Серкіс // Теоретико-методологічні проблеми вдосконалення психологічної підготовки менеджерів : зб. наукових праць. Додаток до наукового журналу «Персонал». - 2000. - № 1 (55). - С. 190-192. 8. Серкіс Ж. В. Про організаційну культуру закладу освіти / Ж. В. Серкіс // Практична психологія та соціальна робота. - 2002. - №9-10. - С. 4-9. 9. Тихомирова О. Г. Организационная культура: формирование, развитие и оценка / О. Г. Тихомирова. - СПб. : Государственный университет ИТМО, 2008. - 154 с. 10. Управление персоналом/ [под ред. Т. Ю. Базарова, Б. Л. Еремина]. - 2-е изд., перераб. и доп. - М. : ЮНИТИ, 2002. - 459 с. 11. Шейн Э. Х. Организационная культура и лидерство / Э. Х. Шейн / [пер. с англ. под ред. В. А. Спивака]. - СПб. : Питер, 2002. - 336 с. : ил. - (Серия «Теория и практика менеджмента»).

\section{SUMMARY}

Timoshko A. Theoretical and methodological basis of organizational culture in theory and practice management general educational institutions.

In the article the relevance of studying organizational culture focuses on the knowledge necessary features of the organizational culture of educational institution that will evaluate as stability schools, its competitiveness, suggest possible directions of management decisions and the ability to achieve planned results. Positioned phenomenon of «organizational culture manager» as a strategic management mechanism, allowing it to focus on competitiveness in a changing educational environment of society.

Professional and cultural aspects common to all members of the educational process of modern school. Cultural pupil - is the product of the teaching staff; 
2016 - № 3 (49)

Cultural teacher - intelligent man for his highest spiritual essence, professional knowledge and creative and humane way of outlook and worldview; highly organized CEI heads with high organizational management culture - a person that fully implements the basic principles of education reform and encourages all participants in the educational process to present the status of the culture of the school.

Mastering new management technology in school management is not possible without understanding the socio-pedagogical foundations of organizational and cultural approach that provides a comprehensive understanding of the evolution and functioning of educational institutions and management. Educational Institutions developing on its special, inherent only their internal laws, by its organizational culture which must be taken into account in the effective management of the institution. Organizational culture - a new area of knowledge, which is a series of management sciences. It is separated from the relatively new field of knowledge of organizational behavior, which studies common approaches, principles, laws and regularities in a particular organization and is part of the concept and phenomenon - culture management.

Key words: organizational culture, organizational culture general educational institution, general manager organizational culture and educational institution, management activities 